\title{
From Fundamental Change to No Change: The NRM and democratization in Uganda
}

\section{William Muhumuza}

\section{(2) OpenEdition}

1 Journals

\section{Electronic version}

URL: https://journals.openedition.org/eastafrica/578

DOI: $10.4000 /$ eastafrica. 578

ISSN: 2790-1076

\section{Publisher}

IFRA - Institut Français de Recherche en Afrique

\section{Printed version}

Date of publication: 1 September 2009

Number of pages: 21-42

ISSN: 2071-7245

\section{Electronic reference}

William Muhumuza, "From Fundamental Change to No Change: The NRM and democratization in

Uganda", Les Cahiers d'Afrique de l'Est / The East African Review [Online], 41 | 2009, Online since 13

September 2019, connection on 09 December 2021. URL: http://journals.openedition.org/eastafrica/ 578 ; DOI: https://doi.org/10.4000/eastafrica.578

\section{This text was automatically generated on 9 December 2021}

Les Cahiers d'Afrique de l'Est / The East African Review 


\title{
From Fundamental Change to No Change: The NRM and democratization in Uganda
}

\author{
William Muhumuza
}

\section{Introduction}

1 Uganda's post-independence period, like in other African states, was afflicted by authoritarian rule, ${ }^{1}$ which led to a development crisis. $^{2}$ In desperate search for remedies, most African states sought donor support. Accordingly, donors have since the 1980s exerted pressure on African states to pursue neo-liberal economic and political reforms. ${ }^{3}$ Whereas donors initially put emphasis on economic reforms, they have since the 1990s added on political reforms arguing that the success of economic reforms is dependent upon political factors. As a result, many African states embraced democratic reforms albeit with serious flaws, ${ }^{4}$ as the case of Uganda demonstrates.

2 It is imperative to note that authoritarian African leaders accepted to undertake democratic reforms in order to access donor assistance. ${ }^{5}$ They harboured a hidden agenda to manipulate them. In the process, many of them have flouted democratic rules by amending constitutions, creating proxy parties, harassing the opposition and organizing flawed elections among others. While formal-legal democratic structures have been showcased, they have had less influence on the politics of these states. ${ }^{6}$ Instead, informal systems manifested in patron-client networks have played an influential political role. Put differently, a neo-patrimonial system characterized by patronage and prebendalism has been used to the peril of democratic rule ${ }^{7}$. Uganda's transition to democracy under Museveni's National Resistance Movement (NRM) regime is a typical case of a flawed democratic transition that has fallen prey to vested political interests and manipulations. ${ }^{8}$ Despite the initial democratic promises by the NRM government, there has occurred a slow but steady reversal of democratization 
since the mid-1990s. There have been clear signs of growing authoritarianism and the hopes of a transitioning to democratic rule have become remote.

3 Uganda's reform experience brings into question the neo-liberal assumption that the acceptance to implement liberal political reforms leads to democracy and good governance ${ }^{9}$. This article begins by looking at the initial populist policies adopted by president Museveni and why he later abandoned them. It then examines political manipulations used to further and entrench his personal rule at the cost of democratic consolidation. The article also analyses why donors, who have been crucial to Uganda's recovery, are indifferent to a flawed democratic transition. Lastly, it discusses the implications of a flawed democratic process for Uganda's political future.

\section{The promise of "fundamental change"}

During the swearing in ceremony on 29 January 1986, Museveni promised Ugandans a fundamental change: "No one should think that what is happening today is a mere change of guard; it is a fundamental change in the politics of our country." 10 The promise created a lot of expectations within the population after many years of despair. The country had gone through tough times due to bad governance from 1966 to 1986. This period witnessed unprecedented authoritarian rule characterized by institutional decay and political insecurity, ${ }^{11}$ which adversely affected the economy ${ }^{12}$ In response to the crisis, people retreated from the formal institutions of the state and organized parallel informal structures as coping mechanisms. ${ }^{13}$ The consequence was a dysfunctional state. Otherwise, it would not have been possible for Museveni's ragtag guerrilla army that started fighting with 27 guns to overthrow a legitimately elected government within a period of only five years.

5 Museveni's promise of fundamental change took cognizance of the fact that Ugandans had lost trust in the state and subsequently denied it legitimacy. He knew that without restoring hope, it would be difficult to get popular support for his young and fledgling government. Prior to capturing power, Museveni lacked a serious support base within the country, the very reason why he opted for a protracted civil war. He had through his Uganda Patriotic Movement (UPM) party, competed for and lost the 1980 elections. His party won a single seat in parliament. Although there were claims of election rigging by Obote's Uganda People's Congress (UPC), ${ }^{14}$ Museveni's UPM party was new and little known in the country and therefore could not marshal serious support. Uganda's politics had been dominated by the two traditional parties of UPC and Democratic Party (DP) since independence. Therefore, Museveni desperately needed legitimacy for his young NRM government to survive. It is for this reason, that he promised a fundamental change from the onset.

6 As promised, the NRM government embarked on a number of populist reforms as outlined in the Ten-Point programme-a policy document written in August 1981 by the NRM guerrillas to guide them once in power. ${ }^{15}$ Key among the policies, was the introduction of participant grassroots structures, initially known as Resistance Councils (RCs) later (1993) renamed Local Councils (LCs). The RC structure had five hierarchically linked tiers namely, the village council (RC1), parish council (RC2), subcounty council (RC3), county council (RC4) and district council (RC5). While council members for RC1 were democratically elected through adult suffrage, the councils of the remaining tiers were indirectly elected.${ }^{16}$ In essence, the adoption of the RCs helped 
to rebuild the administrative structure of the collapsed state. The RCs also provided a democratic climate for citizens to effectively participate in public decision-making. ${ }^{17}$ Other populist reforms included the decentralization of power to local governments, election of people's representatives to the national legislature, affirmative action for women and other marginalized groups, establishment of the offices of ombudsman and Human Rights Commission, pacification of the army, allowing civil society to organize freely, and writing a new constitution among others. The political and economic reforms introduced in the first ten years of the NRM government popularized the regime. The new grassroots institutions also helped to legitimize the NRM government.

The semblance of formal-legal democratic institutions created an impression that the NRM government was on the right path to democratic rule. It is therefore not surprising that the NRM government got international acclaim. President Museveni was at one time ranked among the "new breed" of African leaders, and the country considered a "beacon of hope" in Africa by the former US Secretary of state, Madeline Albright. Therefore, the implementation of popular governance reforms improved the country's image at home and abroad. This helped to stabilize the country internally and attract generous foreign aid.

During the first ten years, the NRM leadership embraced participatory politics and tolerated divergent political views. Evidence of political tolerance can be exemplified by President Museveni's first cabinet, which was all-embracing and broad based. ${ }^{18}$ It drew members from the NRM, traditional political parties and other shades of political life. It tried to accommodate Uganda's religious, regional and ethnic social diversities. These populist policies were intended to unify and stabilize the country especially after many years of political dislocation. Accordingly, popular avenues were used to review some of the existing institutions such as the constitution. This process culminated into the writing of a new Ugandan constitution of 1995, which was a product of wide consultations that represented a broad spectrum of Ugandan political views. ${ }^{19}$ In addition, new institutions such as the Uganda Human Rights Commission and the Inspectorate of Government (IGG) were created. Nonetheless, the democratic transition process has since 1996 got derailed. The question posed by this paper is what motivated President Museveni to pursue democratic reforms in the initial period but later abandon them?

\section{Motivating factors for pursuing populist reforms}

Museveni's initial attempts to pursue populist reforms can be attributed to a number of factors. First, he was able to capture power partly because of his popular appeal especially to the rural people. In stark contrast with the predecessor government, the National Resistance Army (NRA), a guerrilla force, had excellent relations with the local people in the occupied parts of the country. People in liberated zones were organized into RCs, which gave material and political support to the NRA. The RC structure was gradually rolled over to all parts of the country after the NRM captured power. Through affirmative action policy initiatives, the NRM also won the support of women, youth and the disabled. Therefore, Museveni's re-introduction of political participation generated a massive rural support base and legitimacy for the NRM government, which it desperately needed for stability and nation-building. It should be noted that while 
Ugandans experienced relative democracy briefly (1962-1965), the period from 1966 to 1986 witnessed unprecedented levels of authoritarian rule.

The other objective of initiating populist reforms was to undercut the power base of traditional political parties, which posed a threat to the NRM's hold on power. Ugandans had since the struggle for independence subscribed to two major political parties of UPC and DP. Despite having a countrywide appeal, the two parties were sectarian in nature. ${ }^{20}$ Therefore, for Museveni's NRM to penetrate the Ugandan political scene, it was imperative to weaken the influence of the two sectarian parties. This was effectively done through RCs, which were popular, participatory and non-sectarian. RCs attracted tremendous popular support because they were viewed as a uniting factor in a nation torn by many years of social divisions and strife. Therefore, without providing a viable option in form of popular grassroots structures such as RCs, Museveni and his NRM government would have found it difficult to wrestle influence from the two traditional political parties.

Another explanation for Museveni's initial democratization efforts was the desire for international recognition and support. It should be remembered that African states had been afflicted by despotic and corrupt regimes. ${ }^{21}$ Hence, Museveni had to demonstrate to both the local people and international community that his regime had democratic credentials. Coupled with this, his ascendancy to power occurred at a time when donor support was tied to pursuing neo-liberal economic and democratic reforms. ${ }^{22}$ As earlier pointed out, Museveni had inherited a failed state and shattered economy. Therefore, successful reconstruction required enormous donor support that could only be accessed through adhering to donor policies. Although Museveni was initially an ardent student of Marxist ideas and a strong critique of World Bank and IMF policies, he had to abandon this position by May 1987 and embrace Western-sponsored market and democratic reforms. ${ }^{23}$ This ideological shift was inevitable if his government was to access the much needed donor support to reconstruct the economy, which had big implications for the survival of his regime. The sudden shift to pursue neo-liberal reforms attracted substantial support from the IFIs and bilateral aid.

However, it should be realized that President Museveni implemented populist reforms not because he subscribed to democratic ethos but for purposes of strengthening his hold on power. It ought to be noted that he was never subjected to any elections from 1986 to 1996. During this period, the NRM monopolized power. Although political parties were not banned, their activities were restricted to party head offices. Hence, it can be argued that President Museveni used populist appeals such as the reforms mentioned above to consolidate his power base.

\section{The implementation of pseudo-democratic reforms, 1996-2006}

13 The period from 1996 onwards marked a shift from the all-inclusive and broad-based politics of national unity to politics of exclusion and manipulation. In short, it was no longer necessary for President Museveni to have a broad-based government because the ten years in power had helped him consolidate his power base by building a strong grassroots network and military machine. Besides, the state and economy had been 
reconstructed and the country was relatively stable. Hence, Museveni's position was stronger than ever before both domestically and externally.

Despite the various economic and political accomplishments of the NRM government, donor and domestic pressure continued to be exerted on government to open up political space for competitive politics. Previously, President Museveni was able to resist these pressures by arguing that he wanted to rebuild the country first and subsequently create a stable environment for competitive politics. This argument was however dismissed by local critics who contended that Museveni was afraid of competitive politics and intolerant to divergent views ${ }^{24}$. Whereas President Museveni had an advantage of incumbency, he still feared opening up for competitive multiparty elections and instead opted for gradual and pseudo democratic reforms. The reason for doing this was to avoid being ostracized by donors, which would have been costly in terms of losing external economic support. Besides, he also wanted to silence his domestic critics (especially the multiparty advocates), that the NRM needed more time to complete the democratic reform process, especially after the writing of the new constitution in 1995.

to quell internal and external pressures, President Museveni opted for a gradual but slow political transition to competitive politics based on individual merit ${ }^{25}$ as opposed to partisan politics in 1996. It should be pointed out that the constitutional making commission whose members were handpicked by President Museveni, had recommended that party activities be suspended for five more years after which the decision would be reviewed through a referendum. This position was upheld by the Constituent Assembly (CA), which was dominated by NRM delegates. The temporary suspension of party activities was eventually provided for under Article 269 of the 1995 Constitution. As a consequence, the 1996 elections were organized under the individual merit framework, a principle that was upheld by the 2000 referendum.

Hence, the political transition was securely placed under the control and influence of Museveni's NRM government. The only concession was to open up for individuals from any political persuasion to compete for power at all levels of government on the basis of individual merit but not parties. This was justified on the grounds that multipartism would return sectarian politics and consequently polarize the country. This allowed the NRM to implement piecemeal democratic reforms, which were manipulated to ensure that Museveni maintains political control. It is not until 2005 that change to multiparty politics was approved. It should be pointed out that Museveni opted for this change because it suited his vested political interests. He made this concession in order to get a new lease of political life and bounce back as a president under a different political dispensation. He needed to assure donors that Uganda was steadily transiting to multiparty democracy so as to continue getting aid.

17 On the question of quest for a new lease of political life, the 1995 Constitution had mandated two presidential term limits, which in the case of President Museveni was to expire in 2006. Therefore, his personal effort to campaign for the opening up of multiparty politics in 2005 referendum ${ }^{26}$ was in preparation for prolonging his stay in office as president under the new multiparty political dispensation. He was sure that the national support enjoyed by the NRM would make it easy to win elections. After all, the traditional parties had been in limbo for two decades. Hence, Museveni successfully manipulated the NRM party structures and got re-elected as the flag bearer of the newly re-branded National Resistance Movement Organization (NRM-O) party for 2006 
elections. Therefore, President Museveni has since 1996 been using political manipulations, patronage politics and neo-patrimonialism to entrench his personal power at the cost of democratization as elaborated in the proceeding section.

\section{Politics of manipulation, patronage and neo- patrimonialism}

President Museveni's determination to retain power in a pseudo democratic dispensation has culminated into many undemocratic practices. It has been driven by the motive to marshal enough political support in order to retain power. This objective has largely been achieved through different political maneuvers that have included manipulating the laws and processes of the political transition. A case in point is the attempt by President Museveni to undermine the independence of parliament so that it serves the vested interests of the NRM government. This process began with the creation of the NRM caucus in parliament in 1998. The main objective was to ensure that NRM parliamentarians (MPs) agree on a common position before engaging in parliamentary debates. Prior to this innovation, MPs engaged in parliamentary debates without their party's encumbrances. The free and independent atmosphere gave an opportunity to parliament to check the executive and bring sanity to politics. A case in point was the parliamentary censuring of four corrupt NRM ministers. Nonetheless, President Museveni did not want a strong parliament because it would frustrate his political interests, the very reason he mooted the idea of forming the NRM caucus with a chief whip to navigate it along an agreed upon government position. The new approach has since given opportunity to the majority NRM members to influence the direction of parliamentary debates. However, the disadvantage with caucus politics has been the stifling of the independence and free thinking of NRM legislators. In circumstances where some NRM MPs have defied the NRM common position, President Museveni has threatened to withdraw support from them in the next elections. ${ }^{27}$ Therefore, the parliament has lost its significance as a pillar of democratic rule because of such manipulations.

The NRM government has also increasingly extended material and political support to its supporters at all levels of government. The nature of support has varied from job rewards to government contracts and political appointments. ${ }^{28}$ Similarly, the President has frequently promised to reward or rewarded areas that support his government with district statuses. ${ }^{29}$ Besides, the critical and outspoken NRM and non-NRM political aspirants have on various occasions been politically bought off in order to enhance the NRM's support. ${ }^{30} \mathrm{~A}$ typical example is when NRM MPs were bribed to campaign against the freeing of parties in the 2000 referendum. A similar approach was successfully used to entice the NRM MPs to support the freeing of parties in the 2005 referendum. A more vivid example of NRM's bribery tactics to manipulate the democratic process involved the amendment of the 1995 Constitution to lift presidential term limits. In this particular case, 223 out of 333 MPs were each given five million shillings to support the amendment of Article 269. ${ }^{31}$ Conversely, critics who want meaningful democratic change have been harassed and purged. Cases in point include the Young Parliamentarians Association (YPA) whose members resisted the executive's influence on parliament and fought corruption in government by censuring four corrupt but powerful ministers..$^{32}$ A closely related example is the dropping of four ministers in 
2003 who were openly opposed to amending the constitution to lift presidential term limits in order to allow Museveni to have a third term..$^{33}$ As a consequence of such manipulations, outcomes of parliamentary debates have increasingly been influenced to pursue interests of the NRM government. ${ }^{34}$

Another clear manifestation of manipulative politics of the NRM is elections. The NRM government has at various times manipulated election laws in order to have an unfair advantage over the other political contestants. In other words, the level playing field has been lacking. Evidence of this started with the 1989 National Resistance Council (NRC) elections. In 1986, President Museveni promised Ugandans that he would rule for four years after which national elections would be held. However, only elections for members of NRC were held in 1989 though in a highly manipulative way. In order to ensure that President Museveni's NRM had majority members in the NRC, elections were called at short notice. These elections were based on individual merit principle as opposed to party affiliation and did not allow open campaigning. Joint meetings were organized where candidates were only allowed to introduce themselves to voters. The law setting up the NRC was also manipulated to reserve nearly a quarter of the total seats ( 68 out of 280 seats) to be appointed by the president. These included 38 seats for NRM historical, ${ }^{35} 20$ NRC members and 10 more seats for NRA council (army). By successfully manipulating the composition of NRC, Museveni was able to retain his position of president without being subjected to elections. ${ }^{36}$ His term of office was extended for four more years on the pretext to complete the ongoing reforms such as the process of writing a new constitution that was supposed to pave way for transition to democratic rule, which was completed in 1995.

Related to the above example, the President always begins presidential campaigns before the designated period on the pretext that he is sensitizing people to fight poverty. Moreover, elections held under the NRM government in 1996, 2001 and 2006 have been afflicted by rampant acts of bribery. Money and material things were reported to have been extensively used to woe voters. ${ }^{37}$ Besides, the neutrality and independence of the Electoral Commission (EC) has become the subject of serious contention, more especially, where the EC commissioners are appointed by the president. This explains why it has been organizing disputed elections that are characterized by inflated voter numbers, ${ }^{38}$ faulty registers, insufficient civic education, and rigging ${ }^{39}$ to mention but a few. The major criticism is that the EC is a partisan body biased towards the NRM. These practices have not only marginalized the opposition but have made Uganda's transition to democratic rule superficial. ${ }^{40}$

It should also be pointed out that Museveni's determination to retain power has degenerated into militarization of politics. ${ }^{41}$ Not only has President Museveni kept a strong grip on security forces through appointing and promoting loyal cadres to top positions ${ }^{42}$ but has also purged those insubordinate and disloyal to him. The ten army MPs are strictly supposed to toe the NRM line. This was exemplified when the two army MPs who stubbornly tried to toe an independent line were recalled and punished. ${ }^{43}$ The army is also frequently deployed during presidential elections purportedly to keep peace. However, critics argue that the purpose of deployment is to intimidate and harass voters to vote for the NRM since keeping law and order is a mandate of the Uganda police force. This may be true since some senior army officers occasionally threaten that they will not accept to be ruled by opposition leaders. ${ }^{44}$ Besides, some reports have documented acts of security forces being partisan and also engaging in 
political violence and intimidation during elections. ${ }^{45}$ The army's involvement in Uganda's politics has been exaggerated to the extent that it is represented in parliament, some army generals serve as ministers, civil servants and head the police force. All these cases among many others are a testimony of President Museveni's personalization of the army ${ }^{46}$ and using it to entrench himself in power while growing intolerant to people with divergent political views. Hence, Uganda's political transition can be rightly defined as illiberal democracy. ${ }^{47}$

Attempts have also been made to intimidate and manipulate the Judiciary to serve as a tool to further the interests of Museveni's NRM but without much success. He has on various occasions criticized the judiciary for being corrupt and undermining his government especially where judges rule against the interests of government. ${ }^{48}$ Such controversies came out more vividly when Justice Kanyeihamba of the Supreme Court openly disagreed with the president about the role of peasants in determining the country's destiny. Whereas Museveni argued that peasants should always be involved in deciding pertinent constitutional matters such as lifting the presidential term limits, Kanyeihamba differed in opinion citing the fact that peasants may not have the expertise and experience that is sometimes necessary and/or may be prone to government manipulations in reaching such vital decisions. The president became furious and threatened the judge. ${ }^{49} \mathrm{~A}$ related incident involved the High Court's decision to give bail to suspected members of Dr. Kizza's Forum for Democratic Change (FDC) who were accused of waging an armed rebellion against the government through the People's Redemption Army (PRA). The High Court released them on bail since they had already spent more days in jail than those mandated by law. This infuriated government which re-arrested and placed new charges on them. Again, on suspecting that the High Court was going to release them on bail, government deployed military commandos who besieged the High Court..$^{50}$ This action was intended to intimidate the judiciary and to refrain it from pursuing an independent line. It was a clear message to the judiciary that it should avoid antagonizing government positions.

Another case concerns the office of the Inspector General of Government (IGG), which was created to fight corruption and abuse of office. This is one of the institutions that were created but not given the necessary power to function effectively. The law creating this institution was drafted in such a way that made it a lame duck. Rather than make the institution independent and report to parliament, its head was appointed by and reported to the president. The IGG was also supposed to investigate cases of corruption and abuse of office after which the reports would be forwarded to the Director of Public Prosecution (DPP) to prosecute the culprits. This made the IGG's office a paper tiger. Many of the cases of corruption and abuse of office involving high profile political leaders that were forwarded to the DPP have been either shelved or government has lost interest in them purportedly because of lack of sufficient supporting evidence. ${ }^{51}$

All these examples provide ample evidence of how president Museveni's NRM government created institutions for advancing democratic governance for symbolic purposes. He was pretty aware that such institutions would legitimize his government domestically and before donors. Rather than promote democratization, these institutions have been systematically manipulated to promote vested political interests of Museveni and subsequently entrench him in power. The president prefers to work through informal networks of patronage and clientele networks to run government. 
These networks are generously rewarded ${ }^{52}$. One of the examples that can be cited is the president's meeting with local leaders and notables from various parts of the country, which are held at his Rwakitura country home especially towards elections. Such meetings are alleged to be aimed at compromising them politically using material rewards and promises. A related example is the Entandikwa micro-credit scheme which was initiated by the NRM government in preparation for the 1996 elections. Over Shs 9 billion was loaned to the poor all over the country. Each constituency was allocated Shs 30 million of which the beneficiaries were to be identified by local council officials. The LC structure was largely dominated by NRM-leaning councilors who passed on these funds to their supporters ${ }^{53}$. This money is strongly believed to have tilted the tide of support in favour of Museveni's NRM during the 1996 elections. The above examples and other forms of neo-patrimonialism have been used by Museveni to build a support base that has been crucial for his personal entrenchment in power.

\section{Explanations for donor indifference to Uganda's flawed transition}

It is also imperative to ask why donors who normally put a lot of pressure on other undemocratic African states have kept a blind eye on Museveni's NRM regime. There are three main explanations for donor indifference. The first explanation is because the NRM government successfully implemented donor-sponsored economic reforms and has been showcased by donors as a star performer and model for other post-conflict African states. Besides, donors having injected substantial aid to Uganda, were hesitant to portray their experiment as a failure..$^{54}$ Instead, they thought they would engage it and gradually change it. In other words, donors could not afford to disown their successful experiment. They believed, perhaps unwittingly, that with more reforms and some little pressure the regime would gradually democratize.

The second explanation is that President Museveni hoodwinked donors to believe that his government was indeed seriously implementing democratic reforms. He pursued a deceptive approach where his government slowly put in place formal democratic institutions and processes. Yet, these institutions and processes were for symbolic purposes since they were never given the necessary power to function effectively. Instead, President Museveni continued to rely on neo-patrimonialism that involves working through informal channels as opposed to mainstream formal institutions and processes.$^{55}$ Therefore, this deception created an impression not only to the donors but also to the local political players that the country was on the right course to democratization. However, with time, it has become clear that President Museveni has been pursuing personal interests of entrenching himself in power at the expense of Uganda's democratization. ${ }^{56}$ This scheme was exposed after 2001 elections when he pushed for the amendment of the constitution to drop the presidential term limits so that he gets a third term.

The third explanation is that donors were slow at pushing the NRM government to democratize because of strategic interests. Uganda was considered to be one of the very few "beacons of hope" in a region torn by civil and political strife. Many of the regional states such as Burundi, Rwanda, Congo and Sudan were engulfed in civil wars while Kenya was also experiencing intermittent civil strife especially in the rift valley area, which eventually exploded after the 2007 elections. The fact that the Uganda 
government was an oasis of relative stability in a region torn by conflict and its president being an ally of the West, convinced donors to opt for a softer approach.

\section{Implications of flawed democratic reforms}

During the period 1986-1996, Museveni's government created an impression that it was on a steady path to strengthen democratic institutions such as the army, judiciary, legislature, and local governments. Nonetheless, these institutions have ended up being used for propaganda purposes. They have not been enabled to perform their duties independently. Therefore, Museveni's motive to retain power in a pseudo democratic dispensation has significant implications for Uganda's political future.

The use of political manipulations such as bribery has dire consequences for Uganda's democracy. It implies that people will no longer choose their leaders on merit. Besides, it is most likely to institutionalize corruption in government. Public officials who win elections through bribery will increasingly resort to corrupt behaviour in order to recoup what was invested in politics as well as accumulate more resources in preparation for future elections. The buying off of influential opposition members also negatively affects Uganda's democratic prospects since the opposition will be weakened and hence unable to check excesses of the incumbent government as well as offer policy alternatives.

Museveni's unwillingness to leave power, through political manipulations and personalization of power may negatively affect Uganda's political stability. Personalization of power leads to authoritarianism and corruption that may reverse Uganda's current gains. This is because as avenues for peaceful political engagements get closed, people who yearn for democratic change could resort to violent means to change government. In other words, as democratic avenues get closed, the possibility of coups, terrorism and guerrilla wars become the option. In the interest of stability, development and continuity, the political transition to democratic rule should not be sacrificed for personal interests. Instead emphasis should be put on institutionalization of Uganda's politics, which helps to build consensus especially in the context of a multiethnic society underpinned by diverse and conflicting interests.

Moreover, Museveni's politics of patronage and neo-patrimonialism may have negative consequences for the economy. Rather than use national resources for priority development programmes, they are instead wasted on rewarding loyalty, buying off opposition, bribing voters and investing in forces of coercion. It is evident that the NRM regime has opportunistically wasted scarce resources on forces of coercion and a blotted administrative apparatus to accommodate political supporters to the disadvantage of development. ${ }^{57}$ For instance, Museveni has 58 personal assistants and advisors ${ }^{58}$ in addition to his government's bloated establishment of 69 ministers, 333 MPs and over 80 districts to mention a few. Despite calls by domestic and external forces to reduce the size of government, Museveni has ignored them because he is well aware that patronage politics necessitates such sacrifice.

Contrary to the neo-liberal assumptions that the implementation of political reforms would lead to democratization and good governance in Africa, the reverse has been the case. Instead, underlying the pseudo democratic reforms has been political manipulations, patronage and neo-patrimonial politics. The sponsors of these reforms are partly responsible for this negative development because they have portrayed 
double standards, especially where their actions have been overridden by their selfish national interests. In the case of Uganda, although the NRM frequently claims to have created the necessary conditions for democratization such as having the relevant laws, institutions and practices in place, it is still questionable whether this symbolism can be equated with democratization. It is not only a matter of having the formal-legal democratic institutions and processes in place, but these must be empowered and must be seen to function effectively. Besides, a conducive democratic climate must be guaranteed. Such an environment includes, but is not limited, to having fair and effective laws and institutions but also tolerance of divergent political views, political accountability, fairness of play and respect for each other. Given the absence of these important political principles, the democratization process in Uganda is at the crossroads.

\section{BIBLIOGRAPHY}

Apter, David E. (1995). “Democracy for Uganda: A Case for Comparison.” Daedalus, 124 (3): 155-91. Barkan, Joel, Kayunga, Simba, Ngethe, J.D.S. \& Titsworth, N. (2005). The Political Economy of Uganda: The Art of Managing a Donor-Financed Neo-Patrimonial State. Kampala: World Bank Commissioned Report.

Bayart, Jean-Francois (1993). The State in Africa: The Politics of the Belly. London: Longman. Bwengye, Francis A.W. (1985). The Agony of Uganda: From Idi Amin to Obote. London: Regency Press Ltd.

Callaghy, T.M. (1987). “The State as a Lame Leviathan: The Patrimonial- Administrative State in Transition.” In Zaki Ergas (ed.), The African State in Transition: 87-116. London: Macmillan.

Cammack, Dianna (2007). “The Logic of African Neo-Patrimonialism: What Role for Donors?" Development Policy Review 25 (5): 599-614.

Ddungu, Expedit (1989). Popular Forms and the Question of Democracy: The Case of Resistance Councils in Uganda. Working Paper 4. Kampala: Centre for Basic Research.

Furley, Oliver \& Katalikawe, James (1997). “Constitutional Reform in Uganda: The New Approach.” African Affairs 96 (383): 243-61.

Hauser, Ellen (1999). “Ugandan Relations with Western Donors in the 1990s: What Impact on Democratization?” Journal of Modern African Studies 37: 621-41.

Huntington, Samuel P. (1993). “Democracy's Third Wave.” In Larry Diamond \& Marc F. Plattner (eds.), The Global Resurgence of Democracy: 3-25. Baltimore \& London: The Johns Hopkins University Press.

Huntington, Samuel P. (1991). The Third Wave: Democratization in the Late Twentieth Century, Norman (OK) \& London: University of Oklahoma Press.

Joseph, Richard (1998). “Africa, 1990-1997: From Abertura to Closure.” Journal of Democracy 9 (2): 3-17. 
Karugire, Samwiri R. (1980). A Political History of Uganda. London: Heinemann.

Karugire, Samwiri R. (1988). Roots of Instability in Uganda. Kampala: Fountain Publishers.

Kasfir, Nelson (1991). “The Uganda Elections of 1989: Power, Populism and Democratization.” In Holger Bernt Hansen \& Michael Twaddle (eds.), Changing Uganda: 247-78. Kampala: Fountain Publishers.

Kasfir, Nelson (1983). "State, Magendo and Class Formation in Uganda." The Journal of Commonwealth and Comparative Politics 21 (3): 84-103.

Lancaster, Carol (1988). “Policy Reform in Africa: How Effective?” A Journal of Opinion 16 (2): 30-35. Mugyenyi, Joshua B. (1991). "IMF Conditionality and Structural Adjustment under the National Resistance Movement." in Holger Bernt Hansen \& Michael Twaddle (eds.), Changing Uganda: The Dilemmas of Structural Adjustment and Revolutionary Change: 61-77. Kampala: Fountain Publishers. Muhumuza, William (2007), Credit and the Reduction of Poverty in Uganda. Kampala: Fountain Publishers.

Muhumuza, William (1997). "Money and Power in Uganda's 1996 Elections." African Journal of Political Science 2 (1): 168-79.

Museveni, Yoweri K. (1997). Sowing the Mustard Seed. London: Macmillan.

Mutibwa P. (1992). Uganda since Independence: A Story of Unfulfilled Hopes. Kampala: Fountain Publishers.

Mwenda, Andrew M. \& Tangri, Roger (2005). "Patronage Politics, Donor Reforms, and Regime Consolidation in Uganda." African Affairs, 104 (416): 449-69.

Oloka-Onyango, Joe (2004), “'New Breed.' Leadership, Conflict, and Reconstruction in the Great Lakes Region of Africa: A Sociopolitical Biography of Uganda's Yoweri Kaguta Museveni." Africa Today 50 (3): 29-52.

Republic of Uganda (2002). Report of the Select Committee on Election Violence. Uganda Parliament, September 2002

Sandbrook, Richard (1985). The Politics of Africa's Stagnation. Cambridge: Cambridge University Press.

Schultheis, Michael J. (1975). “The Ugandan Economy and General Amin, 1971-1974." Studies in Comparative International Development, 10 (3): 3-35.

Tangri, Roger \& Mwenda, Andrew M. (2006). "Politics, Donors and the Ineffectiveness of AntiCorruption Institutions in Uganda." Journal of Modern African Studies 44 (1): 101-24.

Villadsen, S. \& Lubanga, Francis, eds. (1996). Democratic Decentralization in Uganda: A New Approach to Local Governance. Kampala: Fountain Publishers.

Watson, Catherine (1994). “No to Multi-Party.” Africa Report 39 (3): 24.

Wiebe, Paul D. \& Dodge, Cole P., eds. (1987), Beyond Crisis: Development Issues in Uganda. Kampala: Makerere Institute of Social Research.

World Bank (1996). World Development Report, 1996 (From Plan to Market). Washington (D.C.): The World Bank.

Zakaria, F. (1997). “The Rise of Illiberal Democracy.” Journal of Democracy 76 (6): 22-43. 


\section{Press}

Amanyire, Sam \& Basiime, Felix (2008). "I am Going Nowhere - Museveni.” Daily Monitor, February 14, 2008: 1-2.

Bifubyeka, Ebenezer (2004). "Big Government Cripples the Economy." The New Vision, February 17, 2004: 8 .

Etengu, Nathan (2004). “Gen. Museveni Slams Judge Kanyeihamba.” The New Vision, March 22, 2004: $1-2$.

Gyezaho, Emmanuel (2005). “Col. Bogere Martyrdom: So Why Have Army MPs?” Daily Monitor, July 6, 2005: 19 .

Gyezaho, Emmanuel (2004). “223 MPs got Shs 5M Cash.” The Monitor, November 16, 2004.

Kaheru, Hamis (2004a). “Museveni Defends MPs Cash.” The New Vision, November 1, 2004: 1, 3.

Kaheru, Hamis (2004b). “Army to Remain in Politics.” The New Vision, July 8, 2004: 4.

Kalinaki, Daniel K. (2006). “How Votes were stolen in 2001.” Sunday Monitor, February 12, 2006: 12.

Kasasira, Risdel, Nalugo, Mercy \& Nalugo, Emmanuel (2008). "Land Bill: Museveni to Fail Dissenting MPs." Daily Monitor, March 4, 2008: 1-2.

Kategaya, Eriya (2005). “Will the UPDF be Impartial During and After Kisanja." Sunday Monitor, May 1, 2005: 7.

Kigambo, Gaaki (2005). “Is Museveni Deliberately Militarizing the Police?” Sunday Monitor, November 27, 2005: 14.

Mafabi, David \& Mulumba, Badru D. (2004): “Museveni Vows to Fix Kanyeihamba." The Monitor, March 22, 2004: 1-2.

Mao, Norbert (2005). "Cabinet Reshuffle is Victory of Loyalty over Competence." Sunday Monitor, January 16, 2005: 7, 21.

Mao, Norbert (2004). "Rise and Decline of Young MPs.” The Weekly Observer, April 8, 2004.

Matsiko, Grace (2005a). "Political Calculations Guided the Latest Promotions in Military.” Sunday Monitor, February 6, 2005: 10.

Matsiko, Grace (2005b). “Museveni Offers Sh. 1 b to Maj. Mutale's KAP.” Sunday Monitor, February 20, 2005: 1-2.

Monitor Reporters (2005). "Referendum Must be Held - Museveni”, The Monitor, April 27, 2005: 12.

Monitor Team (2006). “Feb. 23 Rigging Makes my Heart Bleed-Cardinal.” Daily Monitor, April 17, 2006: 1-2.

Mugisa, Anne (2005). “Bogere to Face Army Council.” The New Vision, July 4, 2005: 1-2.

Mukose, Abubaker (2004). "Parliament Now Liberated, Says M7.” The New Vision, December 24, 2004: 1-2.

Mulondo, Emmanuel (2006). “NRM Kills Parliamentary Opposition in its Infancy.” Daily Monitor, May 31, 2006: 17, 36.

Mulondo, Emmanuel (2004). “NRM Losers get Appointments.” Daily Monitor, December 15, 2004: 5. 
Mulondo, Emmanuel \& Nandutu, Agnes (2005). "House Approves 20 More Districts.” Daily Monitor, July 21, 2005: 3 .

Mulumba, Badru D. (2005). “1 Million Ghosts on Voter Register.” The Monitor, March 29, 2005: 1-2. Musoke, Cyprian \& Namutebi, Joyce (2008). "Reduce Presidential Advisers, MPs.” The New Vision, September 3, 2008: 2 .

Mutaizibwa, Emmy (2004). “High Command: Will Museveni ever Let go the Army?" Sunday Monitor, October 17, 2004: 16.

Mutumba, Richard \& Natabaalo, Grace (2006). “Uganda's Crisis Started with the Militarization of Politics.” Sunday Monitor, June 25, 2006: 16-17.

New Vision (2004). “Museveni Mad with Judges over Nullifying 2000 Referendum Act." The New Vision, June 30, 2004: 20-21.

Nyakairu, Frank (2006). “2,400 New Poll Stations Trigger Fear of Rigging.” Daily Monitor, January 16, 2006: 1-2.

Olupot, Milton (2006). "Voters are 10.4 Million." The New Vision, February 9, 2006: 1.

Olupot, Milton \& Mukasa, Henry (2005). “MPs Approve Twenty New Districts.” The New Vision, July 21, 2005.

Ogoola, Justice James (2005). “Uganda Military Rapes the Temple of Justice.” Sunday Monitor, November 20, 2005: 28.

Osere, Emojong (2008). “Army will Not Allow ‘Bad People’ to Rule-Aronda.” Daily Monitor, September 1, 2008: $1 \& 2$.

Vision Reporter (2002). “Army Leads in Poll Violence.” The New Vision, May 27, 2002: 1.

\section{NOTES}

1. Karugire (1980). Also see Karugire (1988), Mutibwa (1992).

2. Sandbrook (1985).

3. Huntington (1991).

4. Joseph (1998); also see Zakaria, F. (1997). “The Rise of Illiberal Democracy.” Journal of Democracy 76 (6): 22-43.

5. Lancaster (1988).

6. Cammack (2007).

7. Mwenda \& Tangri (2005).

8. Barkan et al. (2005).

9. World Bank (1996).

10. Museveni, Yoweri K. (1997).

11. Wiebe \& Dodge (1987).

12. Schultheis (1975).

13. Kasfir (1983).

14. Bwengye (1985).

15. Watson (1994). 
16. Villadsen \& Lubanga (1996).

17. Ddungu (1989).

18. Oloka-Onyango (2004).

19. Furley \& Katalikawe (1997).

20. Apter (1995).

21. Bayart (1993).

22. Huntington (1993).

23. Mugyenyi (1991).

24. Oloka-Onyango (2004).

25. The principle of individual merit entails an individual standing for election to a political post on the basis of personal qualities as opposed to party backing.

26. Monitor Reporters (2005).

27. Kasasira et al. (2008).

28. Mulondo (2004).

29. Olupot \& Mukasa (2005). Also see Mulondo \& Nandutu (2005).

30. Mao (2005).

31. Gyezaho (2004). Also see Kaheru (2004a).

32. Mao (2004).

33. Tangri \& Mwenda (2006).

34. Mukose (2004).

35. The NRM Historicals comprised of core cadres of the NRM during the guerrilla war.

36. Kasfir (1991).

37. Muhumuza (1997).

38. Mulumba (2005). Also see Nyakairu (2006), Olupot (2006).

39. Monitor Team (2006). Also see Kalinaki (2006).

40. Mulondo (2006).

41. Kigambo (2005); Kaheru (2004b); Kategaya (2005); Mutumba, \& Natabaalo (2006).

42. Matsiko (2005a).

43. Mugisa (2005); Gyezaho (2005).

44. Osere (2008).

45. Republic of Uganda (2002). Also see Vision Reporter (2002).

46. Mutaizibwa (2004).

47. Zakaria (1997).

48. New Vision (2004).

49. Etengu (2004); Mafabi \& Mulumba (2004).

50. Ogoola (2005).

51. Tangri \& Mwenda (2006).

52. Matsiko (2005b).

53. Muhumuza (2007).

54. Hauser (1999). 
55. Callaghy (1987).

56. Amanyire \& Basiime (2008).

57. Bifubyeka (2004).

58. Musoke, Cyprian \& Namutebi, Joyce (2008). "Reduce Presidential Advisers, MPs." The New Vision, September 3, 2008: 2.

\section{AUTHOR}

\section{WILLIAM MUHUMUZA}

William Muhumuza (PhD) is an Associate Professor in the Department of Political Science and Public Administration, Makerere University, Uganda. 